\title{
EVIDENCE-BASED APPROACHES IN CHILDREN WITH HYPOTHERMIA
}

\author{
Nazlı Melis MISYAĞCI ${ }^{1,2}$, Çiğdem Müge HAYLI'1,3* \\ ${ }^{1}$ Cyprus Science University, Institute of Health Sciences, Nursing Department, 31, Girne, North Cyprus Turkish Republic \\ ${ }^{2}$ Gebze Technical University, Graduate School of Science, Department of Molecular Biology and Genetics, 41400, Kocaeli, Turkey \\ ${ }^{3}$ Koç University Institute of Health Sciences, Child Health and Disease Nursing, 34450, Istanbul, Turkey
}

\begin{abstract}
The normal level of functioning of various metabolic processes in our body depends on normal body temperature. It is very important to maintain the patient's normal body temperature before, during, and after surgery to prevent possible complications. The occurrence of postoperative hypothermia is higher than hyperthermia. Pediatric hypothermia is a condition that needs to be prevented. Today, the use of various methods helps to prevent hypothermia; and guidelines exist for the prevention and management of hypothermia, supported by research that makes this process more reliable. With this mini-review, we aim to create a common multidisciplinary approach to prevent hypothermia. This study is about the current views addressing the maintenance of normal body temperature and discusses the risk factors predisposing to hypothermia and the goals of evidence-based hypothermia management in pediatric patients.
\end{abstract}

Keywords: Pediatrics, Evidence-based, Thermoregulation, Heat management

\begin{tabular}{|c|c|}
\hline \multicolumn{2}{|c|}{$\begin{array}{l}\text { *Corresponding author: Koç University Institute of Health Sciences, Child Health and Disease Nursing, 34450, İstanbul, Turkey } \\
\text { E mail: chayli17@ku.edu.tr (C.M. HAYLI) }\end{array}$} \\
\hline Nazlı Melis MISYAĞCI $\quad$ (iD) https://orcid.org/0000-0002-8569-9580 & Received: January 09, 2021 \\
\hline https://orcid.org/0000-0001-7630-9619 & $\begin{array}{l}\text { Accepted: January 24, } 2021 \\
\text { Published: May 01, } 2021\end{array}$ \\
\hline
\end{tabular}

\section{Introduction}

Fever is one of the body's defense mechanisms. It is not only a 'symptom' but it is also referred to as a 'disease' itself. Because, pediatric patients, respiratory distress, metabolic acidosis, hypoglycemia that may develop due to hypothermia, hypoxemia, cardiac disorders, coagulopathy and wound site compared to adults against complications such as infection is more vulnerable (Bajwa, 2016). Fever occurs when there is an imbalance in the thermoregulation center that controls the body temperature in response to several factors such as infection, edema, and tissue damage (Gökçay, 2001; Husain and Coleman 2002; Yalçın 2002). Fever helps the body to fight against infections by altering the ideal reproductive environment for microorganisms (Kara, 2003).

Hypothermia is a decrease in the body temperature below $35^{\circ} \mathrm{C}$ (Girişgin, 2006; Chawla et al., 2020). If the child is constantly exposed to a cold environment, it also causes hypothermia. Moreover, head trauma, brain tumors, stroke, hypothyroidism, low blood sugar levels, adrenal gland insufficiency, hormonal diseases such as diabetes, serious inflammatory diseases, and drug intoxications are important risk factors for hypothermia (Schnuelle et al., 2019).

Peri-operative hypothermia in pediatric patients has been identified as the cause of negative consequences. Peri-operative hypothermia, prolonged hospitalization increasing the health expenses, increased transfusion requirement, surgical site infection increase the risk and mortality. Heat does not show a homogeneous distribution in the human body. While the heat is concentrated in the core and head regions, it is lower in the peripheral regions (Galante, 2007). That's way mortality increases four times in adult patients with hypothermia, complication rates for sepsis, and myocardial infarction are reported as doubled. Pediatric patients are more likely to experience unwanted hypothermia than adults during surgical interventions are known to be at risk. The frequency of hypothermia in children varies between $42 \%$ and $60 \%$. Hypothermia in pediatric patients occurs due to decreased weight-body surface area ratio and insufficient subcutaneous adipose tissue. The risk of hypothermia is higher in pediatric patients. Peri-operative anesthetics inhibit thermogenesis, resulting in vasodilation and muscle relaxation. In a study, among 530 patients, 78 (52\%) of them had intraoperative hypothermia (Pearce et al., 2010). In a different study, it was stated that internal invasive intervention, age, prolonged anesthesia, blood hypothermia, and blood transfusion decrease the 'decreased body temperature' in children (Leslie and Sessler 2003; Sessler and Forced, 2013; James 2020).

Symptoms of hypothermia are deceleration in body movements and coordination, awkwardness, dizziness, numbness responsiveness to stimuli, slow heart rate, 
slow breathing, confusion, or loss of consciousness (Frank, 2001). The physiological effects of hypothermia depend on many factors. Physiological effects of hypothermia are given in Table 1 (Cobbe, 2012; AST, 2015).

Table 1. Physiological effects of hypothermia

\begin{tabular}{|c|c|}
\hline Metabolic & $\begin{array}{l}\text { Shivering in the postoperative } \\
\text { period increases body oxygen } \\
\text { consumption by } 40 \% \text {. }\end{array}$ \\
\hline Respiration & $\begin{array}{l}\text { Reduces ventilator response to } \\
\text { carbon dioxide. Each degree of } \\
\text { cold reduces the oxygen solubility } \\
\text { (amount of dissolved } \mathrm{O}_{2} \text { ) in the } \\
\text { blood. It reduces the oxygen } \\
\text { affinity of hemoglobin. }\end{array}$ \\
\hline \multirow[t]{2}{*}{ Adrenergic } & $\begin{array}{l}\text { Activation of the sympathetic } \\
\text { nervous system increases the } \\
\text { release of norepinephrine by } \\
100 \%-500 \% \text {. There is little or no }\end{array}$ \\
\hline & $\begin{array}{l}\text { adrenomedullary } \\
\text { (epinephrine and cortisol are } \\
\text { unchanged). }\end{array}$ \\
\hline Cardiovascular & $\begin{array}{lr}\text { Systemic and pulmonary } \\
\text { vasoconstriction } & \text { develops. }\end{array}$ \\
\hline & $\begin{array}{l}\text { Arterial blood pressure increases. } \\
\text { The risk of ventricular } \\
\text { arrhythmias increases. The risk of } \\
\text { myocardial ischemia and cardiac } \\
\text { mortality increases. }\end{array}$ \\
\hline Coagulation & $\begin{array}{l}\text { Platelet function is impaired. The } \\
\text { function of coagulation factors is } \\
\text { impaired. Fibrinolysis develops. }\end{array}$ \\
\hline Immune system & $\begin{array}{l}\text { The function of neutrophils and } \\
\text { macrophages is impaired. The } \\
\text { amount of oxygen in the tissues } \\
\text { decreases. The risk of bacterial } \\
\text { wound infection increases. }\end{array}$ \\
\hline \multirow[t]{2}{*}{ Pharmacokinetics } & $\begin{array}{l}\text { The effect of neuromuscular } \\
\text { blockers is enhanced. The } \\
\text { duration of action of } \\
\text { neuromuscular blockers is }\end{array}$ \\
\hline & $\begin{array}{l}\text { prolonged. For inhaled } \\
\text { anesthetics, the minimum alveolar } \\
\text { concentration is reduced. Renal } \\
\text { blood flow decreases. Liver } \\
\text { functions are reduced. }\end{array}$ \\
\hline
\end{tabular}

\section{Evidence-Based Practices in Children with Hypothermia}

\subsection{Passive Insulation}

While cotton-wool blankets, stockings, and caps are used in services and recovery units; surgical pads, metalreinforced plastic ortular deamel operating rooms can be used. With passive insulation, heat loss can be reduced by up to $30 \%$ (Witt et al., 2013).

\subsection{Active Heating Techniques}

Hot air as one of the active heating methods reduces the heat loss by radiation in blowing systems, it also provides an increase in temperature through convection. These systems are; hot air systems, electrical caps (resistive systems), heat-releasing, intravenous fluid, blood, bloodproduct heaters, (heat energy pads, heat-moisture exchanger filters (Horn et al., 2012).

Special and suitable heating devices are recommended for use with blankets. Low body temperature is detected during the operation period. The blankets are effective devices to warm the patients actively. For example, the blankets can be used as a heating device in operations related to the abdomen, lower chest, upper extremity, head, and face in extremity surgery (Horn et al., 2012).

The second form of active heating is resistive systems (electric, carbon fiber, gel, etc. covers). Some resistive systems may contain water or a special gel. It has been determined that patients may be burnt due to active warming. Because of the electric wires, it is not suitable to use the covers. In the material produced with resistive systems; carbon fiber control units alternatives such as heated blankets suitable size, chest arm blankets are preferred (Hooper et al., 2010).

In studies on hypothermia, the mean of the body temperatures compared to patient groups was $0.41^{\circ} \mathrm{C}$ (moderate evidence) in the first $30 \mathrm{~min}$ after induction and $0.51^{\circ} \mathrm{C}$ higher in the first hour (medium level of evidence) (Matsuzaki et al., 2003). Evidence-based studies on hypothermia prevention methods are given in Table 2 (Hooven, 2011; Witt et al., 2013).

\section{Evidence-Based of Hypothermia Nursing Management}

Prolonged hypothermia increases morbidity and mortality. Prevention of possible complications and to ensure the comfort of surgical patients are important to improve the results. In children, normothermia can be maintained according to evidence-based guidelines. It requires a multidisciplinary approach. (Matsuzaki et al., 2003; Hooper et al., 2009).

Identifying risk factors for hypothermia to measure the body temperature from the recommended areas, to determine the basic comfort level of the child and evaluation of the signs and symptoms of hypothermia are essential. Moreover, application of passive and active heating methods, ringing the room temperature to a level where the patient will not get cold, taking protective measures to maintain normal body temperature for patients and caregivers, and to share these identified risk factors with the surgical team have great importance in clinical practice (Hooper et al., 2009). 
Black Sea Journal of Health Science

Table 2. Evidence-based studies on methods for preventing hypothermia

\begin{tabular}{|c|c|c|c|c|}
\hline Author(s) & Study Type & Number of Cases & Method & Result \\
\hline $\begin{array}{l}\text { Lars Witt et al. } \\
(2013)\end{array}$ & $\begin{array}{c}\text { Prospective } \\
\text { multicenter } \\
\text { observational study }\end{array}$ & 190 & $\begin{array}{l}\text { Intraoperative } \\
\text { Hot Air Blown } \\
\text { System }\end{array}$ & $\begin{array}{c}\text { Decrease in } \\
\text { unwanted } \\
\text { hypothermia }\end{array}$ \\
\hline Wong et al. (2007) & $\mathrm{RCC}$ & 103 & $\begin{array}{l}\text { Preoperative } \\
\text { period }\end{array}$ & $\begin{array}{l}\text { Decrease unwanted } \\
\text { hypothermia carbon } \\
\text { polymer bed reduced } \\
\text { blood loss }\end{array}$ \\
\hline Leeth et al. (2010) & RCC & 105 & $\begin{array}{l}\text { Postoperative } \\
\text { period; hot air } \\
\text { blowing system }\end{array}$ & $\begin{array}{l}\text { Body temperature is } \\
\text { the same amount of } \\
\text { increase in thermal } \\
\text { comfort, cost } \\
\text { reduction }\end{array}$ \\
\hline $\begin{array}{l}\text { De Witte et al. } \\
(2010)\end{array}$ & RCC & 26 & $\begin{array}{l}\text { Preoperative } \\
\text { period; carbonfiber } \\
\text { blanket body } \\
\text { temperature } \\
\text { increase }\end{array}$ & $\begin{array}{c}\text { Postoperative } \\
\text { period; hot air blown }\end{array}$ \\
\hline Hooven (2011) & Cohort & 149 & $\begin{array}{c}\text { Postoperative } \\
\text { period; hot air } \\
\text { blowing system }\end{array}$ & $\begin{array}{l}\text { An increase in body } \\
\text { temperature }\end{array}$ \\
\hline
\end{tabular}

\section{Conclusion}

Using evidence-based guidelines about hypothermia in pediatric groups, determining and applying appropriate warming methods according to body temperature, shortening the time to reach normal body temperature will provide a healthier direction of the process. These activities will positively affect the success of the surgical intervention and the healing process by reducing the frequency of complications caused by hypothermia. For further studies, it is recommended that hypothermia and peri-operative hypothermia should be managed effectively in pediatric patients. It is recommended to determine the methods and practices.

\section{Author Contributions}

NMM; protocol development and research design. NMM and ÇMH; data collection, management and analysis, manuscript writing/ editing, supervision, protocol development. All authors read and approved the final manuscript.

\section{Conflict of Interest}

The authors declare that there is no conflict of interest.

\section{References}

Association of Surgical Technologists (AST). 2015. AST standards of practice form an intenance of normothermia in the periopertive patient, URL: www.ast.org/uploadedFiles/Main_Site/Content/About_Us/S OP_For_Normothermia.pdf (access date: 15.11.2020).

Bajwa SS. 2016. Risk and safety concerns in anesthesiology practice: the present perspective. Anesth Essays Res, 6: 1420.

Billeter AT, Hohmann SF, Druen D, Cannon R, Polk HCJr. 2014. Unintentional perioperative hypothermia is associated with severe complications and high mortality in elective operations. Surgery, 156: 1245-1252.

Chawla S, Bates SV, Shankaran S. 2020. Is it time for a randomized controlled trial of hypothermia for mild hypoxicischemic encephalopathy? J Pediatrics, 220: 241-244.

Chen CL, Chang CL, Lin SJ. 2011. Immediate implant placement and provisionalization with simultaneously guided bone regeneration in the esthetic zone. J Dent Sci, 6(1): 53-60.

Cobbe KA, Di Staso R, Duff J, Walker K, Draper N. 2012. Preventing inadvertent hypothermia: comparing two protocols for preoperative forced-air warming. J Perianesth Nurs, 27: 18-24.

De Witte JL, Demeyer C, Vandemaele E. 2010.. Resistive-heating or forcedair warming for the prevention of redistribution hypothermia. Anesth Analg, 110: 829-833.

Frank SM. 2001. Focus on: perioperative hypothermia consequences of hypothermia. Curr Anaesthesia and Critical Care, 12: 79-86.

Galante D. 2007. Intraoperative hypothermia. Relation between general and regional anesthesia, upper- and lower-body warming: what strategies in pediatric anesthesia? Pediatr Anesth, 17: 821-823.

Girişgin AS, Koçak S, Gül M, Cander B. 2006. Hipotermi ve lokal donmalar. Sürekli Tıp Eğitim Derg, 15: 45-50.

Gökçay G. 2001. Yüksek ateş. URL: http://www.bebek.com/index.asp?bolum=12 \&haberid=333 (access date: 05.10.2020).

Hooper VD, Chard R, Clifford T, Fetzer S, Fossum S, Godden B, Peterson C. 2010. ASPAN's evidence-based clinical practice guideline for the promotion of perioperative normothermia. J Peri Anesthesia Nurs, 25(6): 346-365.

Hooper VD, Chard R, Clifford T, Fetzer S, Fossum S, Godden B, Peterson C. 2009. ASPAN's evidence-based clinical practice guideline for the promotion of perioperative normothermia. J Perianesthesia Nurs, 24(5): 271-287.

Hooven K. 2011. Pre-procedure warming maintains normothermia throughout the perioperative period: a quality improvement project. J Peri Anesthesia Nurs, 26(1): 9-14.

Horn EP, Bein B, Böhm R, Steinfath M, Sahili N, Höcker J. 2012. 
The effect of short-time periods of pre-operative warming in the prevention of perioperative hypothermia. Anaesthesia, 67(6): 612-617.

Husain MA, Coleman R. 2002. Should you treat a fever? Nursing, 32(10): 66-70.

James M. 2020. Newborn with hypothermia. Cases in pediatric acute care: Strengthening clinical decision making. John Wiley \& Sons, Croydon, UK. P: 487.

Kara B. 2003. Review of information related to fever in childhood. Continuing Medical Edu J, 12: 10-14.

Karwowska A, Nijssen-Jordan C, Johnson D, Davies HD. 2002. Parental and health care provider understanding of childhood fever: a Canadian perspective. Canadian J Emerg Med, 4(6): 394-400.

Leeth D, Mamaril M, Oman KS, Krumbach B. 2010. Normothermia and patient comfort: a comparative study in an outpatient surgery setting. J Perianesth Nurs, 25: 146-151.

Leslie K, Sessler DI. 2003. Perioperative hypothermia in the high-risk surgical patient. Best Practice \& Res Clin Anaest, 17(4): 485-498.

Matsuzaki Y, Matsukawa T, Ohki K, Yamamoto Y, Nakamura M, Oshibuchi T. 2003. Warming by resistive heating maintains perioperative normothermia as well as forced-air heating. British J Anaest, 90(5): 689-691.
Pearce B, Christensen R, Voepel-Lewis T. 2010. Perioperative hypothermia in the pediatric population: prevalence, risk factors, and outcomes. J Anesth Clin Res, 1(1): 1-4.

Schnuelle P, Drüschler K, Schmitt WH, Benck U, Zeier M, Krämer BK, Opelz G. 2019. Donor organ intervention before kidney transplantation: a head-to-head comparison of therapeutic hypothermia, machine perfusion, and donor dopamine pretreatment. What is the evidence? American J Transplant, 19(4): 975-983.

Sessler DI. 2013. Forced-air warming in infants and children. Pediatric Anest, 6(23): 467-468.

Witt L, Dennhardt N, Eich C, Mader T, Fischer T, Bräuer A, Sümpelmann R. 2013. Prevention of intraoperative hypothermia in neonates and infants: results of a prospective multicenter observational study with a new forced-air warming system with increased warm air flow. Pediatric Anest, 23(6): 469-474.

Wong PF, Kumar S, Bohra A, Whetter D, Leaper DJ. 2007. Randomized clinical trial of perioperative systemic warming in major elective abdominal surgery. Br J Surg, 94: 421-426.

Yalçın I. 2002. Ateş. 3. Ed., Nobel Tıp Kitapevi, İstanbul, Turkey. $\mathrm{P}: 475$. 